\title{
Shipwreck in the Caribbean Sea: Analysis in the Loss of the U.S.S. Kearsarge-Roncador Cay, Colombia (1894)
}

\author{
William Gomez Pretel \\ International Area \& Cultural Studies, Korea Maritime and \\ Ocean University, South Korea \\ wgomezp77@gmail.com
}

\author{
Jeong, Moon-Soo (corresponding author) \\ Department of European Studies, Korea Maritime and Ocean \\ University, South Korea \\ jms@kmou.ac.kr
}

Publication Information:

Received 3 September 2020, Accepted 22 September 2020, Available online 22 December 2020

DOI: $10.21463 /$ jmic.2020.09.2.02

\section{Abstract}

The United State Ship (U.S.S.) Kearsarge, a Sloop of War, is considering the most famous and glorious ship of the American Civil War after sinking the Confederate State Ship (C.S.S.) Alabama, in 1864 in France. It also represented technological innovations in the second half of the 19th century, combining steam power and sails. After shipwreck on Roncador Cay, Colombia, in 1894, it was abandoned with the armament onboard (seven guns). This paper aims to analyze the causes of the U.S.S. Kearsarge marine accident from the sociocultural factors and environmental conditions, examining the court-martial records, logbook, testimonies, nautical material, and geography in this part of the Caribbean Sea. The article will explore an episode in the United States naval history from a shipwreck that left a mark in the United States (U.S.) Navy and American society from geopolitical and technological context. A court-martial declared guilty of negligence the two officers with the highest rank on board the same year of the accident. The court determined human error from the Commander and lack of support from the navigation officer during the loss of the U.S.S. Kearsarge.

\section{Keywords}

Shipwreck, U.S.S. Kearsarge, Caribbean Sea, Roncador Cay, the United States, Colombia

\section{Introduction}

Humans are living on a planet where three-quarters are covered mainly by water defining the history of humanity. It would be impossible to deny the role of ships and navigation as a part of the development of civilizations and the world as we know it today (Bass, 1972). For that reason, the understanding of how societies built and used ships has significant 
importance as well as the development of technology, especially during war times. However, marine accidents are part of history and were emerged along with ships. The most common causes of shipwrecks during the 15th and the 19th century were extreme climate events, geomorphology, absence of scientific knowledge in navigation techniques, poor design, warfare, and the lack of accuracy in nautical charts (Forsythe et al., 2000; Luckman, 2019).

In order to better understanding the causes of shipwrecks, it requires comprehension of the circumstances surrounding the loss of a ship as a human error or because of environmental conditions. It is essential to establish the geographical area where the incident occurred and identify physical and sociocultural factors affecting navigation such as geomorphology or climate events and geopolitical and technological conditions (Luckman, 2019). Nevertheless, warships have particular implications because of the external pressure of political factors and the Commander's immediate actions during naval operations.

The ships evolved during many centuries of navigation. The 19th century highlights many technological changes, such as adapting sailing design with engines and propellers together, especially the steam-powered warships during the American Civil War (Graham, 1956). During that period, one of the significant shipwrecks was the loss of the U.S.S. Kearsarge, at the end of the century, considered an event of great magnitude for American society. On the one hand, the vessel represents a period of technological changes, a sloop of war under sail and steam power with tremendous advances in naval artillery (Delgado, 2001), and transition from the Civil War to American imperialism. On the other hand, it embodies nationalism, having fought the most critical and prestigious naval warfare of the Civil War in 1864, resulting in the sinking of the Confederate Ship C.S.S. Alabama, in front of Normandy, the coast of France, known as the Battle of Cherbourg (Neyland, 2002; Canney, 1990, p. 84).

The U.S.S. Kearsarge, as Flagship of Admiral Oscar Stanton Commanding the U.S. Naval Force on the North Atlantic Station and Commanded by Commander Oscar Heyerman, was sailing under instructions of the Navy Department from Port Prince, Haiti to Bluefield, Nicaragua to protect American interest in the Caribbean Sea (Lemly, 1894). The ship was grounding and lost with the armament on February 2, 1894, in Roncador Cay, Colombia, without any possibility of been salvaged (Burns, 1894). Today, the shipwreck remains in the Cay, and its exact location is unknown.

The literature review shows the U.S.S. Kearsarge's primary research focuses on its participation during the American Civil War, especially in the Battle Cherbourg, mentioning the shipwreck without further details (Guérout, 1988; Symonds, 2009). Other studies have focused on its design (Canney, 1990), and occasionally its importance as a submerged cultural heritage of the United States mentioned (Dudley, 1998). After the shipwreck of the U.S.S. Kearsarge, a large quantity of information was generated from primary sources such as the logbook, reports of the Commanding officer (Heyerman, 1894), testimonies of the crew, as well as the court-martial (Navy Department, Bureau of Navigation, U.S. Hydrography Office and the Office of the Judge Advocate General, 1894). Later that year, one of the officers present a narrative of the shipwreck (Burns, 1894) without any conclusion on the facts. These documents have not been thoroughly analyzed as an essential source of information.

The finding of the C.S.S. Alabama in 1984 (Guérout, 1988) emphasized the importance of the U.S.S. Kearsarge as an underwater cultural heritage of the United States (Sunken Military Craft Act, 2004) and its relocation through cooperation with Colombia (Dudley, 1998). The present article aims to examine the principal causes of the U.S.S Kearsarge's marine accident from the sociocultural factors and environmental conditions, analyzing geography, testimonies, nautical elements, technology, and the geopolitical context, providing an analytical understanding of the factors and circumstances surrounding this significant loss as a human error. 


\section{Maritime Technology in the U.S.S. Kearsarge}

"The best Vessel of her Class in the Navy." Admiral David Porter, 1883

\section{Sloop of war-from sails to steam}

Understanding maritime technology is fundamental and plays an essential role in interpreting navigation and marine accidents in the 19th century when a transition was possible from sail to steam, as is the sloop of war, the USS Kearsarge (Canney, 1990, p 84). The term sloop was first used to describe a single-masted fore and aft rigged vessel at the end of the 17th century and applied by the Royal Navy to ships with two-masted rigs as "sloop of war." One of the critical factors in designing these ships was incorporating naval artillery in the late 17th and early 19th centuries (Lyon, 1993).

In the early 18th century, the British Navy increased the number of sloops, before the War of Spanish Succession (1714), and spread the term "sloop of war." This class of ships was smaller and faster than a frigate. However, it could supply all the frigate tasks with less crew, armed between 10 and 18 canons, and commanded by an officer who received the degree of "Master and Commander." It was perhaps the most numerous class ever constructed in the Royal Navy (Lyon, 1993).

\section{Design and technology}

The commercial use of the oceans brought several conflicts among European monarchies seeking control of the sea. During the 19th century, a considerable demand in global trade had a big impact on technology in the maritime industry. Actually, during the 1880s, there were more merchant sailing ships than ever before, with significant advances to the shipping industry and suitable designs (Lavery, 2017).

A significant change in ship technology during half of the 19th century was possible due to two main factors, the industrial revolution with the introduction of steam and the expansion of trade where more and faster ships were demanded. The new design was a combination of the wood hull, engines, and screw propels or paddles (Graham, 1956). These new ships with hybrid technology had the quality of not relying entirely on coal ports. However, it gave autonomy to any port on the planet, and the wind gave them additional free propulsion (Lardas, 2011). As for the navigation itself, the changes were in the improvement of nautical watches, sextants, and nautical and pilot charts. Despite this technical transformation, the transition from sail to steam was slow and just possible at the beginning of the 20th century. Early steam warships were an adaptation of sailing design, and Crimea War (1850) showed the importance of steam adaptations to warships. Nevertheless, during this transition, ships continued made of wood (Kaukiainen, 1992).

\section{The sloop Mohican Class and the American Civil War}

American naval history represented more than naval battles. The qualities and characteristics of the ships engaged in war at sea are a prime consideration. Pure sailing ships in the U.S. Navy ended with the U.S.S. Constellation in 1854. The next year moved to steamships with Mohican-class, showing that it was more effective than a massive vessel, carrying 
heavy guns with impressive batteries for its size (Canney, 1990). The steam-powered warships, Mohican Class, represented almost 150 years of evolution. Sloop-rigged warships were snow, ketch, and brigantine rigged and carried up to 12 six-pounder cannons (Musicant, 1995). In 1858, an Act of Congress authorized the first seven sloops. These new ships were fully steam-powered, well ladened with coal, ammunition, and machinery (Baird, 1876; Canney, 1990).

Before the American Civil War, the United States Navy was one of the most powerful navies globally. In this period, the technological advance is unprecedented in navigation with a revolutionary change in armament and steam introduction, where the U.S. Navy participated with a significant contribution. Indeed, the new warships faced revolutionary technology, such as steam power, iron construction, and percussion fuses (Delgado, 2001).

During the war, the strategic aim of the Confederate Navy was a blockade and disrupt the American trade and logistic lines, operating a fleet of commerce raiders, attacking Union merchant ships, and causing significant damage to the economy of the Union. President Lincoln pressure the Secretary of the Navy, Gideon Welles, "to permanently detail a force of fast, powerful, warships to hunt the rebel cruiser down" (Musicant, 1995). As a result, the Union Navy could build more than 600 hundred warships. The majority of the ships were wooden-hulled and three-mastered. When the war ended, the U.S. Navy has some 670 ships (Musicant, 1995; Wyllie, 2007).

\section{The U.S.S. Kearsarge}

The U.S.S. Kearsarge summarizes the United States' nautical history in the second half of the 19th century. The MohicanClass, Slop of War, was designed by William L. Hanscomb (Canney, 1990). It was built under the "1861 Civil War Emergency Shipbuilding program" at Portsmouth Navy Yard, Kittery, Maine, under Isaiah Hanscom's supervision.They used yellow pine, white oak, live oak, iron knees, brackets, and stanchions. The vessel was part of the Union's strategy to establish a blockade of confederate ports (Marvel, 2007).

Launched on September 11, 1861, and commissioned on January 24, 1862, Captain Charles W. Pickering was appointed as a Commander of the three-masted sloops, seven guns, $166 \mathrm{crew}$ members, and displacement of 1,550 tons. The ship was the faster steamer of those days with a remarkable power of speed, an average of thirteen knots with a moderated sea and wind ahead due to her designed and full spread of canvas with engine steam (Badlma, 1894). It was named for a mountain in Carroll County, New Hampshire, which has a name derived from the indigenous word "Kowasadchu," meaning "Pine Mountain" (Gerard, 1898, p. 19).

The original armament of the U.S.S. Kearsarge was two 11- inch Dahlgren smoothbores (cast-iron) mounted on centerline pivots, those were heavy and massive guns with a weighed of $15,700 \mathrm{lbs}$ and 160 inches long, supported by four 32-pounder smoothbore cannon on trucked carriages (Tucker, 2013, p. 1055). All this armament was located in themain deck. In early 1862, one 30 pounder Parrot rifle with a bore of 4.2 inches, and weighed 3,550lbs was added to the forecastle. In 1864, IX-inch Dahlgren replaced the four 32-pounders. At the end of 1886, the ship was placed out of commission in Portsmouth Navy Yard, where it began a series of repairs (The United States Naval History Division, 1971, p. 370).

The vessel was sent in 1887 to Norfolk, Virginia, to continue with the machinery changes (Army and Navy News, 1887, p. 12). Besides, significant modifications were made in the armament before being into service. The two XI-Inch Dahlgren shell guns were converted (changed) into 8-inch rifles in the 1870s by inserting an 8-inch rifled sleeve down the muzzle. As a result, they were chambered to fire an 8-inch rifle round (E, Farrell, personal communication, March 1, 2020). 


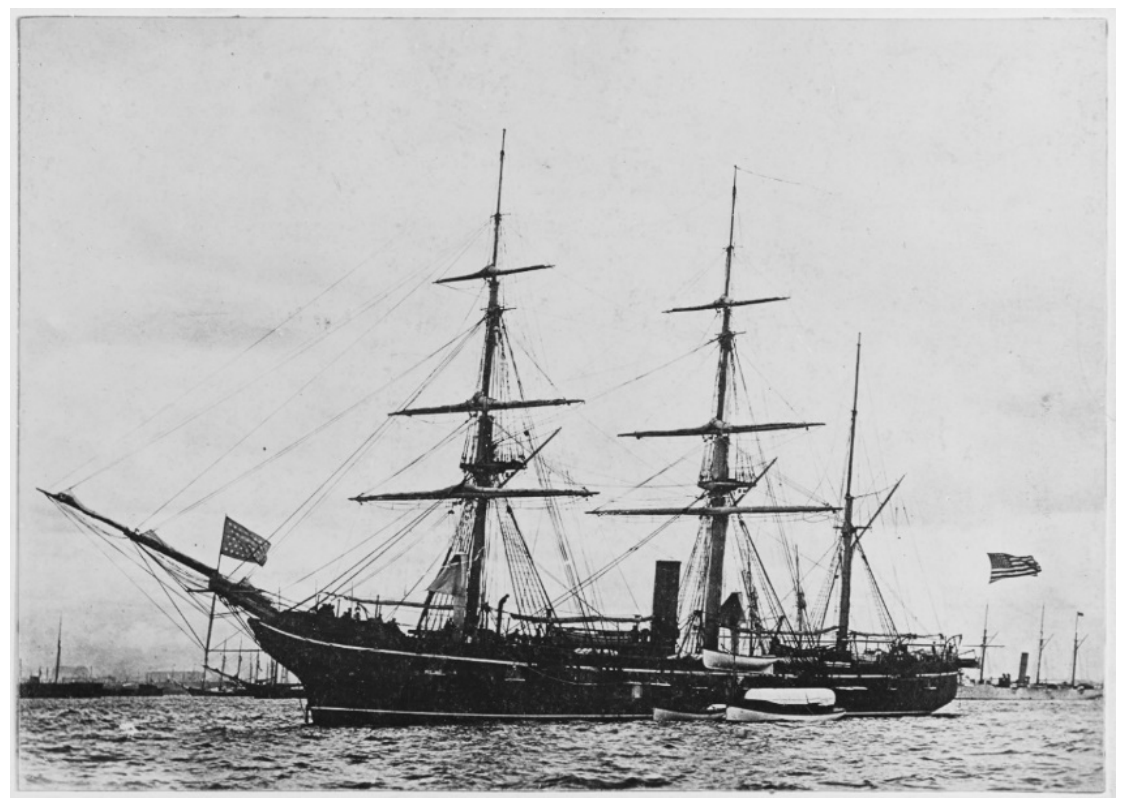

Fig 1. The U.S.S. Kearsarge (1862-1894) - Photographed in New York Harbor, in about 1890.Source: U.S. Naval History and Heritage Command. Catalog \#: NH 63151 (2020).

After the Civil War, the Kearsarge has active participation in the West Indies (Caribbean Sea). In 1888, due to different situations that threatened the "American interest in the West Indies," particularly on Haiti Island ("The Haytian Problems," October 30,1888), the Government requested urgent intervention whit the participation of a warship in the region. The Navy decided to send the U.S.S. Kearsarge once its repairs were completed under the North Atlantic Station assignment. From November of 1888, until its shipwreck in Roncador Cay, in 1894, the U.S.S. Kearsarge completed different military missions in the Caribbean region's domestic affairs, highlighting its participation in political events that occurred in Venezuela in 1892 (The United States, Naval History Division, 1971, p. 370).

Finally, maritime technology gives some details for better comprehension of how this ship operated with two forms of energy besides the armament modifications, which are very important for a future project to identify the wreck of the U.S.S. Kearsarge through the armament.

\section{Western Caribbean Sea: A Strategic Space}

The Caribbean is an area full of maritime history and has been an essential and strategic space (Mintz, 1974). Likewise, it presents navigation hazards due to environmental conditions such as geomorphology and extreme climate events, which are the principal causes of ship losses in this area since the 15th century (Rappaport, Fernández-Partagás, 1997, pp. 97-98; Trouet et al., 2016, p. 3173). Thus, it is essential to understand the area and its geography for navigation. 


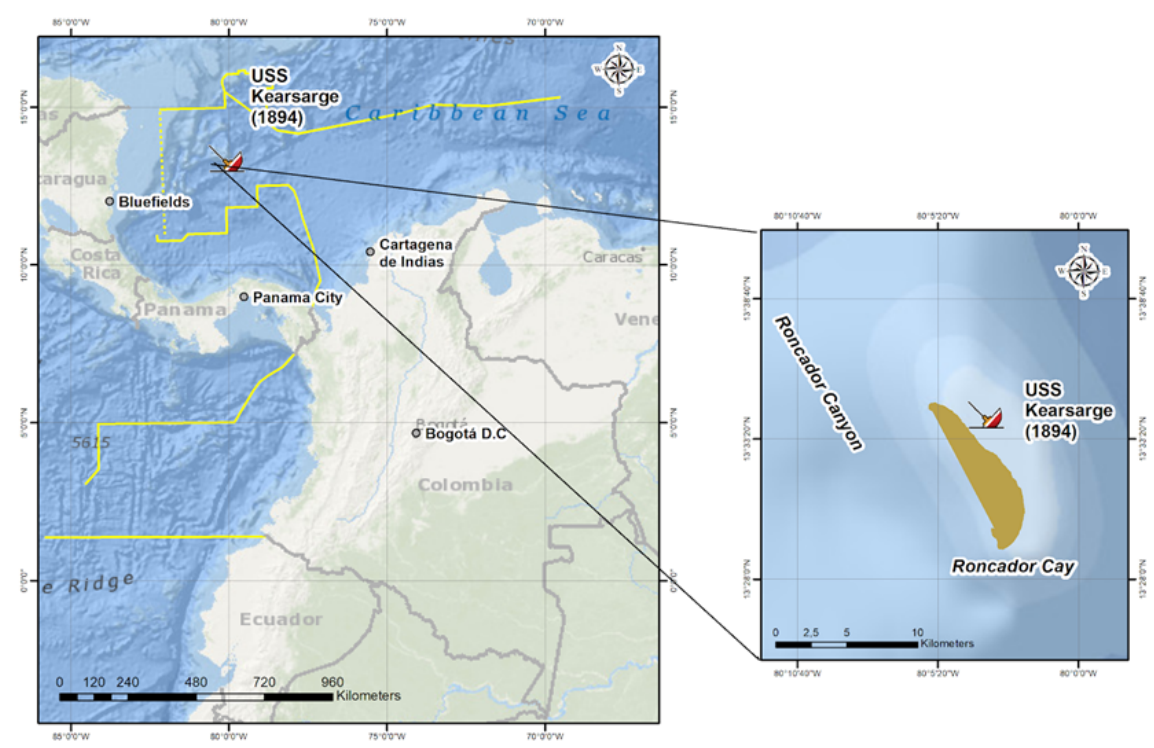

Fig 2. Roncador Cay in the Western Caribbean Sea, near to Panama Canal. Note: Roncador Cay is part of Colombia since its independence from the Spanish Crown at the beginning of the 19th century. Own elaboration.

From the 15th to the 19th century, the sea's control was particularly disputed by colonial powers, especially the British and Spanish empires. Navigation was the method to conquer this geographical space. As a result, extensive trade between the American continent and Europe was generated with new maritime traffic routes across the Atlantic (Grugel, 1995; Gomez, Carvajal, 2011, pp. 180-181).

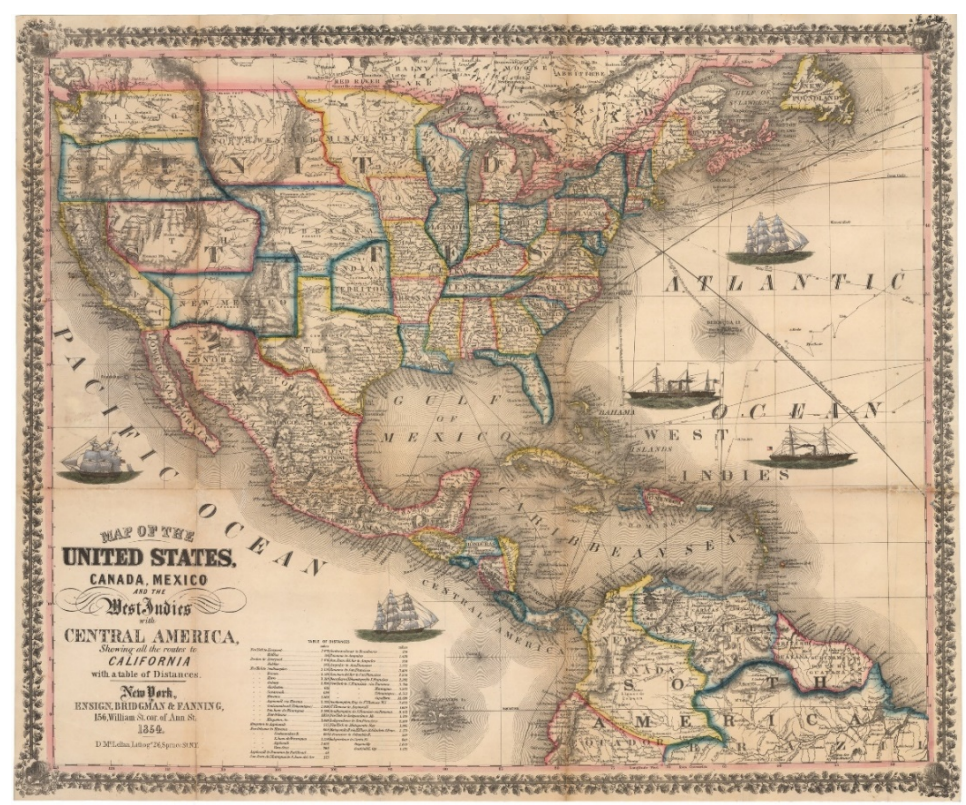

Fig 3. Map of the United States, Canada, Mexico, and the West Indies with Central America, showing all the routes to California with a table of distances-1854. Note: The map was published in New York by Ensign, Bridgman \& Fanning firm. Source: University of California-UCLA, library. Department of Special Collections, Charles E. Young Research Library, U.C. Los Angeles. Identifier: uclamss_990_b31_4 (2020). 
During the middle of the 19th century, this route was reactivated, particularly for the California gold rush phenomena, considering one of the most massive mass migration in American history (Rohrbaugh, 1997). This migration signifies a new trade route connecting the Pacific with the Atlantic through the Isthmus of Panama with the railroad system (Delgado, 1990). Besides, the United States' constant military and naval presence after the American Civil War due to imperialist interest increased navigation in the Caribbean Sea (Bosch, 2009, pp. 7, 11). This influence was endorsed by the post-war Navy that developed an impressive growth and strengthening of new tactics and strategies in naval warfare, establishing the importance of a blue water navy (Neyland, 2014).

At the end of the 19th century, the Navy Captain Alfred T Mahan's doctrine proposed supremacy and control of the Caribbean as the first line of defense against European powers and extensive knowledge of the geographical areas. This strategy impacted the U.S. Navy and promoted the idea of an interoceanic canal through Panama or Nicaragua (Mahan, 1890, 1890/2012; Pollock, 1982).

Because of this geopolitical and commercial process and the impact of maritime and naval operations, the Caribbean Sea witnessed a considerable number of shipwrecks during the colonial and republican periods. This area contains many archaeological sites that hold a few of the most important underwater cultural heritage sites globally (Leshikar-Denton, 2002).

\section{Nautical description and risk for navigation}

The Archipelago of San Andres and Old Providence, located in the Western Caribbean Sea, is one of the Colombian maritime areas with the most marine accidents giving its strategic location as part of an essential navigation route during world history (Perez J, 2019, pp. 25-26). This geographical space was extensively mapped in an early period since the Europeans arrived on the American continent (Utton, \& Yingling, 2019).

Private geographers provided nautical charts before the hydrographic services, showing the importance and the influence on navigation in the area, but with limited detailed information, notable latitude errors, and lack of scientific precision. Navigators had to use nautical charts with many years of the edition because of the territory's geographical confidentiality due to disputes between colonial powers (Navarro DM, 2003). Nonetheless, in 1795 the United Kingdom Office was established (Wainwright, 2015) and the U.S. Hydrographic Office in 1866, offering better geographical information (Bates, 1956).

Antonio de Herrera y Tordesillas made one of the first nautical studies in the Caribbean Sea in 1601. He included some maps of thisarea in his book entitled "Historia general de los hechos de los Castellanos en las Islas i Tierra Firme del Mar Oceano" (General History of Events of the Castellanos in the Islands and Mainland of Ocean Sea). Besides, Herrera makes a chronicle of Roncador Cayexplaining the navigation between Jamaica and other Islands, and the approach to the coasts of Central America, warning navigators about the danger and risk that Roncador Cay (Herrera y Tordesillas, 1601, pp. 12- 36). John Seller, the hydrographer of the King, described the Caribbean Sea, including Roncador Cay, in the "Atlas minimus, or, A book of geography showing all the empires,monarchies, kingdoms, regions, dominions, principalities and countries in the whole world" (Seller, 1679).

Roncador Cay was the subject of a hydrographic survey by the Spanish Crown as recognition of their colonies in 1810 (Direcciónde Trabajos Hidrográfico, 1810). The survey focuses on the Viceroyalty of New Granada's maritime territory (Caribe Neogranadino) between 1792 and 1810, led by Brigadier de la Armada Don Joaquin Francisco Fidalgo 
(Dominguez et al., 2012). Based on Spanish information, in 1819, the H.M.S. Shearwater (sloop of war) during observation based on two chronometers, determined that Roncador Cay had 18 minutes more eastward and a few bathymetries measurements with low accuracy (Purdy, 1825, p. 54).

Finally, the U.K. Hydrographic Office, between 1828 and 1837, surveyed San Andres and Providence Archipelago with extraordinaryprecision, producing high-quality nautical charts, including Roncador Cay. They used the H.M.S. Jackdaw (wrecked on Old Providence in 1835, commanded by Lt. Barnett) (the United Service Journal, 1835, p. 128), and the H.M.S. Thunder, commanded by Capt. Richard Owen (Purdy, 1845). This information was used for more than a century to produce nautical charts of the Caribbean Sea region.

\section{Reasons for Shipwreck}

For a better comprehension of the shipwreck, the finals moments are examined from the logbook, considering the Commanding officer's decisions, as well as environmental conditions, and navigational hazards in the area. Logbooks have quite important information. Its primary objective is to collect data of events and detailed information of the winds and the weather, which influenced navigation, and speed written by those involved directly (Wheler, Garcia-Herrera, 2008).

After the establishment of the U.S. Navy's Bureau of Navigation in 1862, naval ships began to use printed and standardized logbooks, displaying better and detailed information of climate, leeway, knots, course, observations for local deviation of the ship's compass, and a page for every day of "record of the miscellaneous events of the day," (Bradley, et al., 1978). Nowadays, this information allows the reconstruction of navigation and climate conditions to determine facts during any maritime incident (Wheeler and Garcia-Herrera, 2008).

In November 1893, Commander Oscar Heyerman assumed the command of the U.S.S. Kearsarge, just two months before the accident occurred. His expertise and knowledge of the area were minimal (A new Commander for the Kearsarge, November 23, 1893). The ship with the new Commander sailed from the United States to Haiti at the end of 1893. In January 1894, under cable instructions from the Navy Department, it was ordered to sail to Nicaragua to defend American interest as a flagship of Admiral Oscar Stanton Commanding the U.S. Naval Force on the North Atlantic Station (Lemly, 1894).

The U.S.S. Kearsarge was sailing to Bluefields, Nicaragua, with a plotted course before leaving Haiti. After passing the Island of Navassa, the vessel proceeded with course south-south-west by magnetic compass. Nonetheless, the course was changed on February 2, according to the Commander instructions from south south-west 1/4 west to west shoutwest $3 / 4$ west by compass (Burns, 1894). Once the new course was adjusted, the idea was to sight the Roncador Cay with light day from the north and not from the south. Heyerman's decision obeyed on the strong current in the area that influenced navigation, drifting the vessel to the north. The new course would cause the vessel to pass close to a dangerous area without advice from the officers onboard (Lemly, 1894).

According to the U.S.S. Kearsarge logbook, on February 1, the marine weather conditions were, breeze moderate to fresh from north-east, by east, with force between 4 and 2 knots, stable barometric conditions, with sunset before 06:30 pm, moderate waves (Heyerman, 1894). The next day the logbook did not have entrances due to the officers' negligence on board (Lemly, 1894). The last three days before the accident, the logbook measurements describe the same marine 
weather conditions, indicating the area was not affected by any meteorological phenomena that could alter the navigation (Heyerman, 1894).

These conditions were relatively favorable for sailing. Under those circumstances, the navigation officer, Lieutenant Charles Lyman, did not accurately determine the compass's local deviation. Besides, he did not advise his commanding officer of a safe course when the vessel was approaching a hazardous area and not corroborated the last two observations for longitude before the accident (Burns, 1894).

Two nautical charts were used onboard: Serrana Bank (which included Roncador Cay) (No, 1374. U.S. Hydrographic Office), and EastCoast Central America (No 945.US Hydrography Office), clearly showed the danger of navigating this area. The charts were analyzed by the hydrographic office during the trial, determining that they were based on the chronometric measurements andsurveys made by the Royal Navy in 1835 with "remarkable accuracy based on the scientific possibilities of the moment." (U.S.Hydrographic Office, 1894). Likewise, the North Atlantic pilot chart of 1894 (Sailing Directions for the Gulf of Mexico and the Caribbean Sea) presented information on the physical conditions for that period of the year. This chart was examined during the trial and was found sufficient details of currents to the westward and countercurrents setting northwest, wind speed, and directions in Roncador Cay's area (U.S. Hydrographic Office, 1894; Kelley, 1894).

The sails supported the U.S.S. Kearsarge with a moderate but constant wind in direction east allows the sail to be fully deployed and assisted by steam power with a consistent speed of 8 knots (Heyerman, 1894). The navigating officer's calculations sight Roncador Cay before sunset with a distance of approximately 3 miles to the north, and the Commander was confident about this information (Lemly, 1894). Before the accident, Captain Heyerman left the ship's bridge with some certainty that the Cay was already behind. Before the incident, the lookout reported breaks at port followed by starboard breaks, at a distance fewer than 300 yards. The crew attempted to maneuver but was too late, mainly because the vessel was inside the Cay (Burns, 1894).

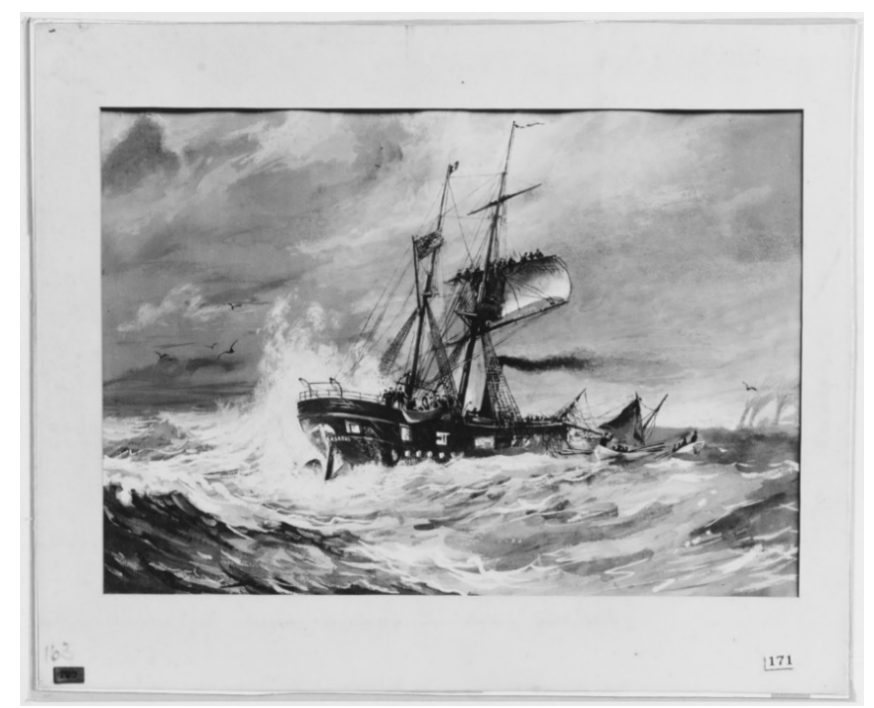

Fig 4. U.S.S. Kearsarge (1862-1894). Watercolor by an unidentified artist, depicting Kearsarge wrecked on Roncador Reef, Caribbean Sea, on February 2, 1894. Courtesy President Franklin D. Roosevelt, 1936. Source: U.S. Naval History and Heritage Command Photograph. Catalog \#: NH 52030 (2020). 
A strong impact was followed by misadjusted guns, and attempts were made to save the vessel, but the U.S.S. Kearsarge would be permanently on Roncador. After the wrecked, the crew remained in the Cay and rescued a few days later, returning to the United States (Heyerman, 1894). The same year, the Commander and navigation officer would face a court-martial and be found guilty of negligence in the U.S.S. Kearsarge's loss (Lemly, 1894).

The court determined that morning and noon observations the day of the accident established the course had been affected by strong currents to the northwest, and the vessel had a drift of thirty-three miles in sixteen hours, more than two knots per hour. This current moved in a different direction as the vessel course, especially in Roncador Cay's area (Burns, 1894, p. 672). Finally, the navigating officer's lack of support added to the Commander's decision to change course, passing through the north part of the Cay instead of the south as planned without a precise analysis of the environmental conditions and navigation hazards, causing the shipwreck of the U.S.S. Kearsarge.

\section{Conclusions}

This research presents an analysis of the sociocultural and environmental conditions, explaining the dangers and risks for navigation, the geopolitical and technological context, and marine accident as a human error. The area may offer a vast potential of underwater cultural heritage because of its strategic location, geomorphology, and tropical cyclones as one of the leading causes of shipwrecks.

The second half of the 19th century represents a crucial period of technological changes that positively affected the navigation, and the U.S.S. Kearsarge symbolizes the dynamism of naval technology combining sails and steam power as a response to the American Civil War. This century would change communications, making them agile with extensive records and information (Kennedy, 1971) to reconstruct historical events such as shipwrecks.

For centuries, cays, banks, and islands in the West Caribbean represent a risk for navigators. The Spanish and British sailing directions mentioned extensive information on the danger they represented, especially in Roncador Cay, because of the currents and the absence of navigational aids. After 1835, the Caribbean Sea and Roncador Cay were subject to an excellent survey by the United Kingdom Hydrographic Office that guaranteed a better understanding of the geographical space with better bathymetry. Nevertheless, there were not enough navigation aids in this area. Although a few years after the U.S.S. Kearsarge episode, a lighthouse was built by the United States government in Roncador Cay in 1919, probably in response to this shipwreck (Department of Commerce, 1920, p. 1407). Subsequent technological advances, especially the radar, would make visible not only other ships at sea but also the morphology of coast and islands, providing a better understanding of the geography, causing a decrease in marine accidents.

Undoubtedly there was a human factor in the U.S.S. Kearsarge accident, but environmental conditions contributed to the shipwreck. Although tropical cyclones rule the area, that time was not hurricane season in the Caribbean Sea (Elsner et al., 2012). Currents were the most considerable dynamic force affecting navigation in the U.S.S. Kearsarge case. Even though currents are not considered dangerous phenomena (Luckman, 2019, p. 105), it interfered with the course established. Besides, geomorphology complexity contributed significantly to the accident, especially the passage between Serrana Bank, Roncador Cay, and Old Providence Island, which was the main obstacle to Nicaragua's route.

The U.S.S. Kearsarge is a source of history and maritime archeology. It is widely considered one of the most valuable shipwrecks in the Caribbean Sea, located in Colombian maritime territory. The vessel is part of the United States' 
underwater cultural heritage (Neyland, 2011, p. 713), representing a shared legacy between the two nations. This shipwreck could be an excellent example of international cooperation similar to the case of the C.S.S. Alabama wreck protection agreement in 1989 between France and the United States (Roach, 1991). Today, its exact location remains unknown within the territorial sea of Colombia. According to some primary sources examined in the article, the vessel was abandoned with the seven guns allowing future identification.

Finally, this research contributes to the underwater cultural heritage and maritime history in Colombia, focusing on the 19th century. It also permits new historical and archaeological studies and future cooperation projects of wrecks in this area.

\section{Acknowledgements}

This work was supported by the National Research Foundation of Korea Grant funded by the Korean Government (NRF2018S1A6A3A01081098).

\section{References}

Army and Navy News, April 1887. The New York Times (online) p. 12. Available at: https://timesmachine.nytimes.com/timesmachine/1887/04/12/100906568.html?pageNumber=12

Baird, G.W., 1876. Pneumatic steering gear, designed for the U. S. sloop of war Mohican and others of the same class. Journal ofthe Franklin Institute. Volume 101, Issue 3, March 1876, pp. 191-193.https://doi.org/10.1016/S0016-0032(76)90416-6

Bass, G., 1972. History of Seafaring: Based on Underwater Archaeology. Thames and Hudson Ltd. London.

Bates, C., 1956. Marine Meteorology at the U. S. Navy Hydrographic Office. A Resume of the Past 125 Years and the Outlook for the Future. Bulletin of the American Meteorological Society, 37(10), pp. 519-527. Available at: www.jstor.org/stable/26245555

Bosch, J., 2009. De Cristóbal Colón a Fidel Castro. El Caribe frontera imperial (Primera edición, 1970). Cámara de Diputados, LX Legislatura; Embajada de la República Dominicana en Méxica; Miguel ángel Porrúa. México, D.F.

Bradley, C., Kurtz, M., Livingston, R., Mulligan, T., Parseghian, M., Vanderveer, P \& Yale, J., 1978. List of Logbooks of U.S. Navy Ships, Stations, and Miscellaneous Units, 1801-1947. National Archives and Records Service, General Services Administration, Special List 44, Washington, pp. $2-12$.

Burns, W., 1894. The Wreck of the Kearsarge: A Narrative. The Proceeding of the U.S. Naval Institute. Annapolis, MD. Vol XXI., No 4. Whole No, 72, pp. 672-690.

Canney, D., 1990. The Old Steam Navy. Volume One. Frigates, Sloops, and Gunboats, 1815-1885. Naval Institute Press. Annapolis, pp. 61-90. Delgado, J., 1990. California by Sea: A Maritime History of the California Gold Rush. University of South Carolina Press, Columbia.

Delgado, J., 2001. Lost Warships: An Archaeological Tour of War at Sea. Checkmark Books, New York.

Department of Commerce, 1920. Commerce Reports. No 153-229. Volume 3. Twenty Second Year-1919. Government Print Office, Washington, P. 1407.

Dirección de Trabajos Hidrográfico, 1810. Derrotero de las islas Antillas de las costas de tierra firme y de las del seno méxicano: formado en la Dirección de Trabajos hidrográficos. Del Orden Superior. Imprenta Real, Madrid. 
Domínguez, O., Salcedo, H., Martin-Meras, L., 2012. Derrotero y Cartografía de la Expedición Fidalgo por el Caribe Neogranadino (1792-1810). El áncora Editores, Bogota.

Dudley, W.S., 1998. American Naval archaeology: Past and prologue. In L.E. Babits and H. Van Tilburg (eds), Maritime Archaeology: A Reader of Substantive and Theoretical. Contributions. Chapter 11. Plenum Press. New York and London, pp. 105-109

Elsner, J.B., Hodges, R.E., Jagger, T.H., 2012. Spatial grids for hurricane climate research. Clim Dyn 39, pp. 21-36. https://doi.org/10.1007/s00382-011-1066-5

Forsythe, W., Breen, C., Callaghan, C., Mc Conkey, R., 2000. Historic Storms and Shipwrecks in Ireland: A Preliminary Survey of Severe Synoptic Conditions as a Causal Factor in Underwater Archaeology. International Journal of Nautical Archaeology 29(2): pp. 247-259. https://doi.org/10.1111/j.1095-9270.2000.tb01455.x

Gerard, W., 1898. The Indian Names of Our War Vessels. Scientific American, 79(2), p. 19. Available at: www.jstor.org/stable/26119208 Gomez, W., Carvajal, A., 2011. Estrategia para la Defensa y Ubicación de las Fortificaciones de la Plaza Fuerte de Cartagena de Indias en el Siglo XVIII a Partir de Condiciones Océano-Atmósfera y Variaciones Morfológicas en la Línea de Costa. Saber, Ciencia Y Libertad, 6(2), pp. 179-192. https://doi.org/10.18041/2382-3240/saber.2011v6n2.2506

Graham, G., 1956. The Ascendancy of the Sailing Ship 1850-85, Economic History Review, Economic History Society. Vol. 9, No 1, pp. 74-88. https://doi.org/10.1111/j.1468-0289.1956.tb02217.x

Grugel, J., 1995. The Historical Evolution of the Caribbean Basin. In: Politics and Development in the Caribbean Basin. Palgrave, London. https://doi.org/10.1007/978-1-349-23975-7_2

Guérout, M., 1988. The Engagement between the C.S.S. Alabama and the U.S.S. Kearsarge May 19, 1864. The Archeological Discovery 19841988. The Mariner's Mirror, 74:4, pp. 355-359. https://doi.org/10.1080/00253359.1988.10656219

Herrera y Tordesilla, A., 1601. Historia general de los hechos de los castellanos en las Islas i Tierra Firme del Mar Oceano. En la Emplenta Real, Madrid.

Heyerman, O., 1894. Logbook of the U.S.S. Kearsarge. 1-28-1894 to 2-1-1894. R.G. 24: Records of the Bureau of Naval Personnel. Log of U.S. Naval Ships, 1801-1915. E-118. PI-1123. Vol 64 of 86. National Archives Building, Washington, DC

Heyerman, O., 1894, February 4. Report from O.F Heyerman to Commander in Chief of U.S. Naval Force. North Atlantic. Roncador Island. R.G. 125. Record of a Court of Inquiry. Exhibit. Navy Court of Inquiry. Entry 30-A. File No, 4854. U.S.S. Kearsarge (Green Box). National Archives Building, Washington, DC

Kaukiainen, Y., 1992. Coal and Canvas: Aspects of the Competition between Steam and Sail, c. 1870-1914. International Journal of Maritime History, 4(2), pp. 175-191. https://doi.org/10.1177/084387149200400209

Kelley, J., 1894. Extract from the Sailing Directions for the Gulf of Mexico and the Caribbean Sea. R.G. 125. Record of a Court of Inquiry. Exhibit. Navy Court of Inquiry. Entry 30-A. File No, 4854. U.S.S. Kearsarge (Green Box). National Archives Building, Washington, DC

Kennedy, P.M., 1971. Imperial cable communications and strategy, 1870-1914. The English Historical Review, Volume LXXXVI, Issue CCCXLI, October 1971, pp. 728-752. https://doi.org/10.1093/ehr/LXXXVI.CCCXLI.728

Lardas, M., 2011. CSS Alabama VS USS Kearsarge-Cherbourg 1864. Osprey Publishing, Midland House. Oxford. The U.K.

Lavery, B., 2017. Ship. 5,000 Years of Maritime Adventure. National Maritime Museum. Dorling Kindersley Limited, London.

Lemly, S., 1894, March 19. Report of the Judge Advocates General of the Navy to the Secretary of the Navy. R.G. 125. Record of a Court of Inquiry. Exhibit. Navy Court of Inquiry. Entry 30-A. File No, 4854. U.S.S. Kearsarge (Green Box). National Archives Building, Washington, DC. National Archives Building, Washington, DC

Leshikar-Denton, M.E., 2002. Problems and Progress in the Caribbean. In International Handbook of Underwater Archaeology, edited by C. Ruppe and J. Barstad, Kluwer Academic/Plenum, New York, pp. 279-298. 
Luckman, G., 2019. Understanding the meaning of Shipwreck: The relationships between Cultural and Environmental Influences in NorthEastern Australia. Historic Environment, Vol. 31, No. 2, pp. 102-113.

Lyon, D., 1993. The Sailing Navy List. All the Ships of the Royal Navy. 1688-1860. Conway Maritime Press (U.K.) Ltd. London.

Mahan, A.T., 1890.The United States Looking Outward, Atlantic Monthly (Dec. 1890), in Mahan, Interest of America (note 45), pp. 4-5.

Mahan, A.T., 2012. The Influence of Sea Power upon History, 1660-1783. New York: Dover (Original work published in 1890).

Marvel, W., 2007. The Alabama \& the Kearsarge: The Sailor's Civil War (Civil War America). The University of North Carolina Press, U.S.A.

Mintz, S., 1974. The Caribbean Region. Slavery, Colonialism, and Racism, 103 No 2, Daedalus, pp. 45-71. Available at: www.jstor.org/stable/20024204 (Access May 8, 2020).

Musicant, I., 1995. Divided Waters. The Naval History of the Civil War. Harper Collins Publishers, New York.

Navarro, M.D., 2003. Idea y Representación del Caribe en la Cartografía española del siglo XVIII. Contrastes: Revista Interdisciplinar de Filosofía 12: pp. 81-92. Available at: http://hdl.handle.net/10261/15110 (Accessed 4 March 2020).

Neyland, R.S., 2002. Preserving and Interpreting the Archaeology of the United States Navy. In: Ruppé, C.V. \& Barstad, J.F. (eds) International Handbook of Underwater Archaeology. The Springer Series in Underwater Archaeology. Springer, Boston, MA, pp. 765-783. https://doi.org/10.1007/978-1-4615-0535-8_46

Neyland, R. S., 2011. Underwater archaeology of the world wars. In Catsambis, A., Ford, B., \& Hamilton, D.L. (Eds.). The Oxford Handbook of Maritime Archaeology. Oxford: Oxford University Press, pp. 708-729

Neyland, R.S., 2014. War at Sea Archaeology. In: Smith C. (eds) Encyclopedia of Global Archaeology. (7678-7686). https://doi.org/10.1007/9781-4419-0465-2_628

Perez, J., 2019. Naufragios Coloniales del Caribe Colombiano. Consideraciones Investigativas, Políticas y Patrimoniales. Memorias: Revista Digital de Historia y Arqueología desde el Caribe. No 38. Universidad del Norte, pp. 7-45. http://dx.doi.org/10.14482/memor.38.986.11

Pollock, T., 1982. The Historical Elements of Mahanian Doctrine. Naval War College Review, Vol. 35: No. 4, Article 7. Available at: https://digitalcommons.usnwc.edu/nwc-review/vol35/iss $4 / 7$

Purdy, J., 1825. Memoir, Descriptive and Explanatory: To Accompany the New Chart of the Atlantic Ocean and Comprising Instructions, General and Particular, for the Navigation of that Sea. Fifth edition; Corrected and Material Improved. Printed, R.H Laurie. London.

Purdy, J., 1845. Memoir, descriptive and explanatory, to accompany the chart of the Northern Atlantic Ocean. Ninth Edition, edited by Findlay, A. Printed for R.H Laurie. London.

Rappaport, E., Fernández-Partagás, J., 1997. History of the deadliest Atlantic tropical cyclones since the discovery of the new world. Hurricanes: Climate and Socioeconomic Impacts, edited by H. F. Diaz and R. S. Pulwarty, Eds., Springer, New York, pp. 93-108. https://doi.org/10.1007/978-3-642-60672-4_5

Rohrbaugh, M., 1997. Days of gold: The California gold rush and the American nation. Berkeley: University of California Press.

Roach, J., 1991. France Concedes United States has Title to CSS Alabama. The American Journal of International Law, 85(2), $381-383$. https://doi.org/10.2307/2203075

Seller, J., 1679. Atlas Minimus, or A Book of Geography: Shewing all the empires, monarchies, kingdoms, regions, dominions, principalities, and countries, in the whole world. Published at his house in Wapping, London.

Sunken Military Craft Act, 2004. SMCA. 10 U.S.C. § 113. Available at: https://www.history.navy.mil/research/underwater-archaeology/policyand-resource-management/sunken-military-craft-act/smca.html

Symonds, C., 2009. The Civil War at Sea. Reflections on the Civil War Era. Greenwood Publisher Group. Santa Barbara, California. 
The Haytian Problems, October 30, 1888. The New York Times (online), p. 3 Available at: https://timesmachine.nytimes.com/timesmachine/1888/10/31/106201289.html?pageNumber=3

The United States Naval History Division, 1971. Civil War Naval Chronology, 1861-1865. Compiled by Naval History Division. Navy Department. Washington.

The United Service Journal, 1835. The United Service Journal and Naval and Military Magazine. 1835 Part III. Courts-Martial. Colburn. London.

Trouet, V., Harley, G. \& Domínguez-Delmás, M. (2016). Shipwreck Rates Reveal Caribbean Tropical Cyclone response to past radiative forcing. PNAS 113 (12) Edited by Kerry A. Emanuel, Massachusetts Institute of Technology, Cambridge, MA, pp. 3169-3174 https://doi.org/10.1073/pnas.1519566113

Tucker, S., 2013. American Civil War: The Definitive Encyclopedia and Document Collection. Volume I: A-C. ABC-CLIO, Oxford.

University of California, 2020. Map of the United States, Canada, Mexico, and the West Indies with Central America, showing all the routes to California with a table of distances Department of Special Collections, Charles E. Young Research Library, and U.C. Los Angeles. Publisher: Thayer, Bridgman, and Fanning (Firm), New York, And N.Y Identifier: uclamss_990_b31_4. Available at: http://content.cdlib.org/ark:/13030/hb9k4012sh/?order=1

U.S. Hydrographic Office, 1894. U.S. Hydrographic Office to Bureau of Navigation. Paper relating to the position of Roncador Reef. No 454,444. Exhibit. G. 125. Record of a Court of Inquiry. Exhibit. Navy Court of Inquiry. Entry 30-A. File No, 4854. U.S.S. Kearsarge (Green Box). National Archives Building, Washington, DC

U.S. Naval History and Heritage Command, 2020. Photograph. Catalog \#: NH 52030 (2020). Available at: https://www.history.navy.mil/content/history/nhhc/our-collections/photography/numerical-list-of-images/nhhc-series/nh-series/NH52000/NH-52030.html

U.S. Naval History and Heritage Command, 2020. Photograph. Catalog \#: NH 63151. Available at: https://www.history.navy.mil/content/history/nhhc/our-collections/photography/numerical-list-of-images/nhhc-series/nh-series/NH63000/NH-63151.html

Wainwright, P., 2015. Developing Hydrographic Services and the Work of the U.K. Hydrographic Office. The International Hydrographic Review, 68(2). Paper presented at the Conference of Commonwealth Surveyors 1991, pp. 54-61. Available at: https://journals.lib.unb.ca/index.php/ihr/article/view/23268

Wheeler, D., García-Herrera, R., 2008. Ships' Logbooks in Climatological Research. Annals of the New York Academy of Sciences, pp. 1146: 115. https://doi.org/10.1196/annals. 1446.006

Wyllie, A., 2007. The Union Navy. Lulu Press, Inc. 